\title{
Rosegarden: LifE ON A LEAF
}

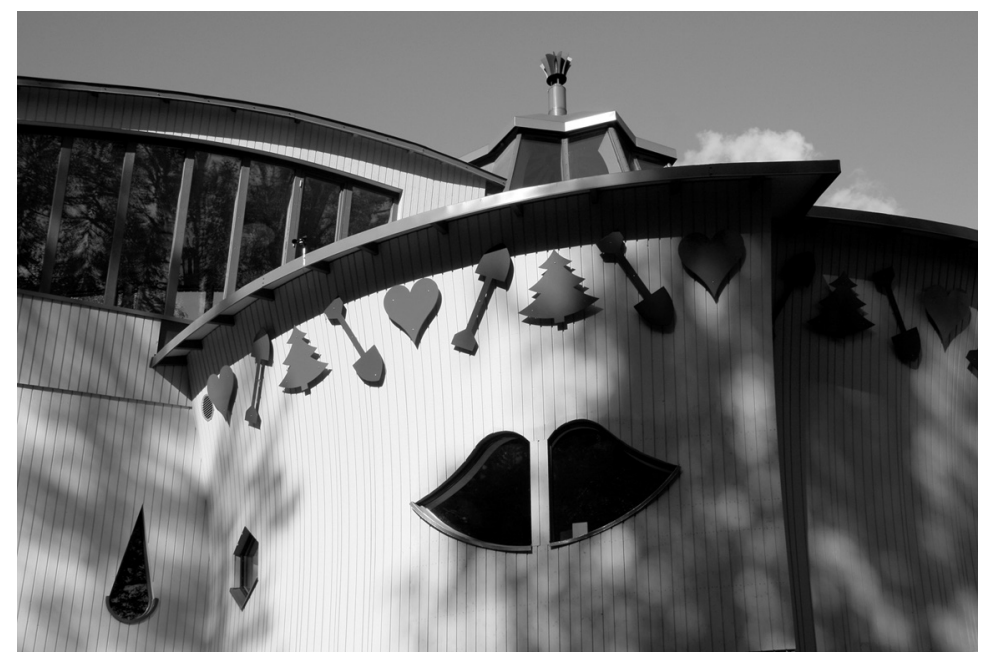

Valokuva: Jan-Erik Andersson.

Kuvataiteilija Jan-Erik Andersson ja arkkitehti Erkki Pitkäranta muodostivat 90-luvun puolivälissä taiteilija-arkkitehti duon Rosegarden: Art and Architecture. Ryhmä on tullut tunnetuksi toteuttamistaan epäsovinnaisista rakennuksista kuten luomunavetta Kumina (Teuva) ja puutarhaoppilaitos Gerbera (Kiipula) sekä lukuisista interiööreistä. Rosegardenin projekteja on esillä internetin osoitteessa http://www.anderssonart.com/rose/garden.htm.

Rosegardenin tähänastinen päätyö on Anderssonin perheelle suunniteltu asuintalo Life on a Leaf, jonka vihkiäisiä vietettiin elokuun lopussa tänä vuonna. Talo sijaitsee Turun Hirvensalossa lähellä Aurajoen rantaa vastapäätä Turun linnaa. Talon suunnittelun ja rakennusvaiheiden dokumentointi sekä suunnitelman taustaideoiden esittely muodostivat Anderssonin kuvataideakatemiaan tekemän tohtorinväitöskirjan, joka tarkastettiin lokakuussa 2008.

Andersson aloittaa talohankkeen esittelyn kotisivuillaan kysymyksella: "Oletko tullut ihmetelleeksi, miksi et koskaan näe maailman miljoonien laatikkomaisten rakennusten joukossa taloa, joka olisi kengän, kukan tai lehden muotoinen?" - Hyvä kysymys. Talot ovat tärkein osa sitä aiemman ihmistyön tuottamaa ympäristöä, jossa me elämme ja joka meitä muovaa. Miksi modernin talon ihanne on betonilaatikko? Toisaalla kotisivuillaan Andersson luonnehtii moderni asuintaloa sanoilla "elämiskone"; Life on a Leaf on Rosegarden duon protesti modernistista elämiskonetta vastaan.

Life on a Leaf on kokonaistaideteos. Andersson on kutsunut mukaan toistakymmentä taiteilijaa, jotka ovat toteuttaneet omia projektejaan sekä talon sisällä että ulkopuolella. Projektit muodostavat yhdessä talon ja sen yksityiskohtien kanssa yhtenäisen mutta tavattoman vaihtelevan ja moniulotteisen kokonaisuuden. Ornamentiikka on Life on a Leaf taloa hallitseva piirre. Väitöskirjansa teoreettisssa osassa Andersson esittää laajan katsauksen mielikuvituksen ja ornamentiikan asemaan arkkitehtuurin historiassa. Rakennusten "funktionaalisuus" ei välttämättä edellytä laatikkomaista muotoa. Asumuksilla voi olla muitakin funktioita kuin niitä, jotka taloudellisimmin jäsentyvät suorakaiteen muotoisiin tiloihin.

Hyvällä ja mielikuvitusta kiehtovalla ympäristöllä on Rosegardenille maailmoja luova eettinen merkitys. Andersson päättää väitöskirjansa toteamukseen "ympäristö, jossa ihmiset elävät hyvin, on myös ekologisesti hyvä ympäristö.” 